\title{
Estimation of the biogas production rate, a chemometrical approach
}

\author{
Tetyana Beltramo ${ }^{1 *}$, Susanne Theuerl ${ }^{2}$, Michael Klocke ${ }^{2}$, Bernd Hitzmann ${ }^{1}$ \\ From 9th German Conference on Chemoinformatics \\ Fulda, Germany. 10-12 November 2013
}

Biogas production rate is an important criterion for the entire biogas production process. In the present study the biogas production rate was evaluated using more than 30 process variables measured at an agricultural biogas plant in Germany during two months. The measured variables include the chemical measurements (such as $\mathrm{pH}$, dried matter, amount of organic acids), energy supply specifications, temperature level and substrate ingredients. The prediction of the biogas production rate was done using chemometric methods. The results of the different methods were compared and the most accurate method was identified. Here the crossvalidated prediction error (RMSECV) computed using leave-one-out method was less than 5 percent for both PCR and PLSR models (less than $190 \mathrm{~m}^{3} / \mathrm{d}$ ), while the calculated correlation coefficient $\left(\mathrm{r}^{2}\right)$ for PLSR reached 0,85 and 0,75 for PCR. For better prediction accuracy a metaheuristic search of the process relevant variables was performed. Here the Ant Colony Optimisation (ACO) improved the prediction performance of PLSR, decreasing the RMSECV to less than 2 percent $\left(95 \mathrm{~m}^{3} / \mathrm{d}\right)$ while increasing the $r^{2}$ to 0,98 . These are promising results, which prove the feasibility of using this evaluation methodology for monitoring in biogas production processes.

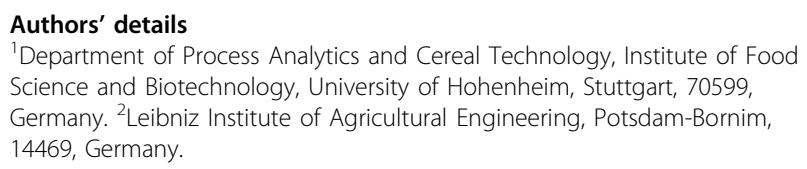

Published: 11 March 2014

\footnotetext{
* Correspondence: t.beltramo@uni-hohenheim.de

'Department of Process Analytics and Cereal Technology, Institute of Food Science and Biotechnology, University of Hohenheim, Stuttgart, 70599, Germany

Full list of author information is available at the end of the article
}

doi:10.1186/1758-2946-6-S1-P26

Cite this article as: Beltramo et al.: Estimation of the biogas production rate, a chemometrical approach. Journal of Cheminformatics 2014 6(Suppl 1):P26.

\section{Publish with ChemistryCentral and every scientist can read your work free of charge \\ "Open access provides opportunities to our colleagues in other parts of the globe, by allowing anyone to view the content free of charge." \\ W. Jeffery Hurst, The Hershey Company. \\ - available free of charge to the entire scientific community \\ - peer reviewed and published immediately upon acceptance \\ - cited in PubMed and archived on PubMed Central \\ - yours - you keep the copyright \\ Submit your manuscript here: \\ http://www.chemistrycentral.com/manuscript/

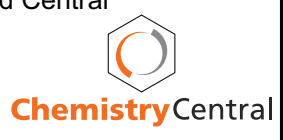

